\title{
Determination of Potential Tourism Using Simple Additive Weighting Based on Geographic Information System
}

\author{
Andrew Kurniawan Vadreas, Dwi Welly Sukma Nirad
}

\begin{abstract}
Padang city has a huge tourism potential, but has not been explored to its full potential. Whereas with the rapid development of technology, tourism sector should be more developed. This research proposes utilization of Simple Additive Weighting (SAW) method. Location and number of tourism data in Padang city were analyzed using SAW method to get spread of location displayed on google maps based on the concept of weighting average or weighting multi-criteria. Mapping of tourism distribution is a variation of color change at the point where the green represents the minimum amount of distribution and the red represents the maximum number. Mapping the location of tourism distribution in Padang city is expected to be considered in improving tourism business by creating new tourism area that can increase the income of local people.
\end{abstract}

Keywords-Geographic Information System (GIS), Simple Additive Weighting (SAW), tourism.

\section{INTRODUCTION}

$\mathrm{I}^{\mathrm{s}}$ $\mathrm{N}$ essence, any kind of tourism development hinges on two elements, mainly destination and market. Through a traditional marketing strategy, using leaflet, booklet, digital media, these two could foster and broaden their marketing scopes. Such breadth in the end will raise the number of tourists, and the marketing development program puts its core in the management of the Tourist Information Center equipped with modern technology [1].

Padang is one of Indonesian cities possessing tourism destinations with a variety of cultures and natural resources. However, it has been managed not appropriately enough. Thus, endeavors are done to raise object development as well as tourism attraction, one of which is through new tourism destinations claiming, place construction and tourism destinations distribution in many locations in Padang. Together, they will create a comfortable, impressive, new tourism object that encourages convention tourism, or more commonly known as MICE tourism (Meeting, Incentive, Conference, and Exhibition), that is harmonious with the objectives and missions of the Padang government. Having that in mind, it is necessary to create a system providing information of areal distribution of tourism destinations so that

Andrew Kurniawan Vadreas, STMIK Indonesia Dwi Welly Sukma Nirad, STMIK Indonesia they could be digitally mapped out.

Geographical Information System (GIS), in the form of both hardware and software, has become the solution of all spatialrelated challenges. It integrates database operation with statistical analysis, offering a unique visualization and spatial observation in the form of virtual map. This ability is what differs GIS from other systems, enabling it to become more trustworthy in providing reality-intact information, predicting results, and strategic planning [2]. This is what happens to the inferring distribution destinations in Padang that uses an GIS to generate a thematic map.

The data analysis applies Simple Additive Weighting technique, which is based on average weighting. Decisions are made directly in determining "relative interest" in each thematic map. Total value of each alternative is obtained by multiplying determined weight on each attribute and adding those attributes. Moreover, the total score of all alternatives is calculated, with the highest being selected [3]. Within a system that provides digital information about the distribution of tourism destinations and their constructions, this research will contribute information on tourism destinations using some data such as those of locations and amount of destinations available in Padang [4].

The SAW method requires a process of (X) matrix normalization into a scale to be compared to any available alternative ratings. Multi-objects are real systems frequently occurring in any colliding multi-objects (like one object fixes and another corrupts). Dimensional analysis may help policy makers to filter better choices in such condition. On the other hand, spatial multi-criteria decision analysis could be an alternative as a process which combines and transforms both spatial and a-spatial input data into resultants (outputs). Multicriteria decision law is also defined as a relation between input map and output map.

Supposing the policy maker fully understands the functional relation in a system, then an index is required to measure its effectivity. However, frequently, a setback may occur in the Multiple Attribute Decision Making (MADM), which is a vector with multiple elements. If those elements are transformed into scalar values, a formulated index is required to calculate each alternative before its highest score gets to be chosen. In understanding the existing functional relation among system-arranging elements, a regression (statistical) 
approach could be used when the policy maker entails the history data system. Unfortunately, this condition is rare in real decision-making process due to an issue of evolution and a complex relation among system-arranging elements. One possible method worth using in such condition is the compensatory method.

\section{RESEARCH METHODOLOGY}

The general data flow of a GIS-based SAW method could be seen on figure 1 .

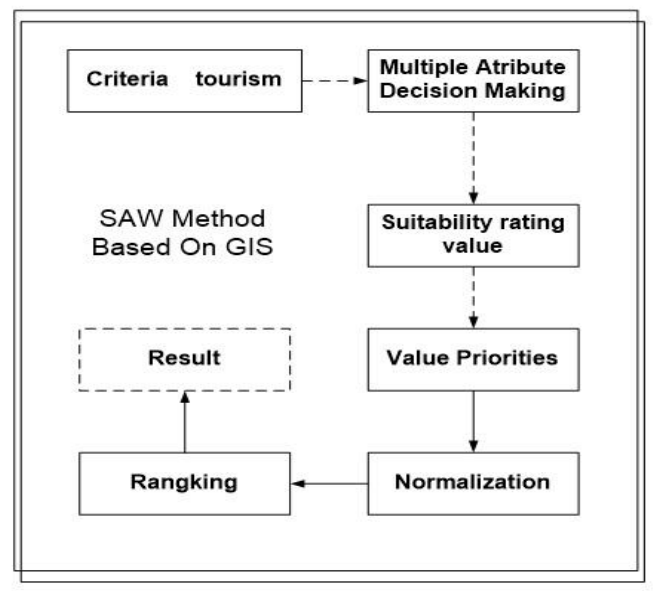

Fig. 1: Data Flow of Tourism Destination using an GIS-based SAW Method

In the SAW method, weight value and ranking are suitable with the determined attribute and alternative. Within the level of criteria/attribute interest, the tourism distribution is also called the criteria evaluation to determine weight value and ranking. For weight value, the calculation starts from "minimum data" with 0 value while "maximum data" with 1 . Using a similar approach, ranking values are determined from "minimum" alternative with 1 in value and "maximum" with 5. Moving on, data criteria are determined by tourism destinations in each sub-district and the number of tourists. To put it more bluntly, the determination of weight value and attribute ranking could be seen on this table.

TABEL I:

DETERMINATION OF WEIGHT VALUE AND ATTRIBUTE RANKING

\begin{tabular}{cccc}
\hline \hline Attribute & Weight & Alternative & Ranking \\
\hline Tourism & 1 & 0 & 1 \\
Destination & & $1-2$ & 2 \\
& & $3-4$ & 3 \\
& & $5-6$ & 4 \\
Number of & 1 & $<6$ & 5 \\
Tourists & & $50,000-000$ & 1 \\
& & $>100,000-200,000$ & 2 \\
& & $>200,000-250,000$ & 3 \\
& $>250,000$ & 4 \\
\hline \hline
\end{tabular}

For the alternative determination, an objective adjustment is used to similarly deviated data before dividing them into 5 rankings. When being determined, each attribute is given the same weight value due to the absence of the standard formula in calculating attribute for the distribution of tourism destination. Value 1 on the weight indicates that this attribute is as important as the other.

Moving on, the alternative ranking value is standardized by dividing alternative ranking value with maximum value. To be precise, the formula would be as follows:

$$
X^{\prime} \text { ij }=\text { Xij / Xjmaks }
$$

In which:

$\mathrm{X}^{\prime} \mathrm{ij}$ is the standardized ranking value for alternative I and attributes $\mathrm{j}$

$\mathrm{Xij}$ is the initial ranking value

Xjmaks is the maximum ranking value of attribute $\mathrm{j}$

This equation will result in such values elaborated on the table below:

TABEL II: WEIGHT VALUE AND STANDARDIZE RANKING

\begin{tabular}{cccc}
\hline \hline Attribute & Weight & Alternative & Ranking \\
\hline Tourism & 0,2 & 0 & 0.2 \\
Destinations & & $1-2$ & 0.4 \\
& & $2-4$ & 0.6 \\
& $5-6$ & 0.8 \\
Number of & 0,2 & $>6$ & 1 \\
Tourists & & 550,000 & 0.2 \\
& & $>100,000-100,000$ & 0.4 \\
& & $>200,000-250,000$ & 0.6 \\
& & $>250,000$ & 0.8 \\
\hline \hline
\end{tabular}

The SAW method is commonly used in facing MADM situations. This method urges policy maker to create weight for each attribute. A total score for an alternative is obtained through adding all resultant multiples between rating (comparable cross-attribute only) and weight of each attribute. The ranking of each attribute must be dimension-free; in other words, it must pass the previous normalization process. Fundamentally, this method is based on the weighing average. Policy makers then directly choose the "relative interest" weight in each thematic map. The total value of each alternative is obtained by multiplying determined weight for each attribute and adding up the resultant attributes. When the score of all alternatives is calculated, the highest value will be chosen. The evaluation of each alternative regulation is as follows:

$$
\mathrm{Ai}=\mathrm{Wj} \mathrm{Xij}
$$

An GIS-based SAW method could be operated using an GIS-system with the overlay technique by providing attribute evaluation to criteria map (input map) that is added up to determine the attribute of the combined map (output map)

\section{DISCUSSION}

The recapitulation of tourism destinations in Padang is based on the sub-district on the table III, from which we can see the distribution of tourism destinations in Padang. However, it still has 11 sub-districts with uneven distribution of tourism destinations. This is because the most common tourism destinations are natural resources. 
TABEL III: TOURISM DESTINATIONS

\begin{tabular}{cll}
\hline \hline No. & Destinations & Location \\
\hline 1. & Pantai Air Manis & Padang Selatan \\
2. & Gunung Padang & Padang Selatan \\
3. & Jembatan Siti Nurbaya & Padang Selatan \\
4. & Pantai Nirwana & Padang Selatan \\
5. & Pantai Pasir Jambak & Koto Tangah \\
6. & Pemandian Lubuk Minturun/Air & Koto Tangah \\
7. & Pemain & \\
8. & Taman Hutan Raya Bung Hatta & Lubuk Kilangan Kilangan \\
9. & Panorama Sitinjau Lauik & Lubuk Kilangan \\
10. & Museum Adityawarman & Padang Barat \\
11. & Taman Ria Pantai Padang & Padang Barat \\
12. & Monumen Merpati Perdamaian & Padang Barat \\
13. & Danau Cimpago & Padang Barat \\
14. & Museum Gempa Padang & Padang Barat \\
15. & The Gate Way of IORA (Indian & Padang Barat \\
16. & Museum Bank Indonesia & Padang Barat \\
17. & Pulau Sirandah & Bungus Teluk Kabung \\
18. & Pulau Sikuai & Bungus Teluk Kabung \\
19. & Pulau Pasumpahan & Bungus Teluk Kabung \\
20. & Pantai Carolina & Bungus Teluk Kabung \\
21. & Pantai Carlos & Bungus Teluk Kabung \\
22. & Pantai Pesona & Bungus Teluk Kabung \\
23. & Gunung Gunung Cindakir Bungus & Bungus Teluk Kabung \\
24. & Air Terjun Lubuk Hitam & Bungus Teluk Kabung \\
25. & Bukit Nobita & Rubuk Begalung \\
\hline
\end{tabular}

This is the overlay of tourism destination map and number of tourists in Padang. This map is the final result of multicriteria decision for distribution of tourism destination using the SAW method displayed in the iridescent part according to the total score after adding up each attribute / arranging criteria. The total score is $1.0-5.0$ which then is divided into 5 classifications in terms of distribution of tourism destination. The green part shows an area with minimum level of distribution, and red part shows maximum level of distribution.

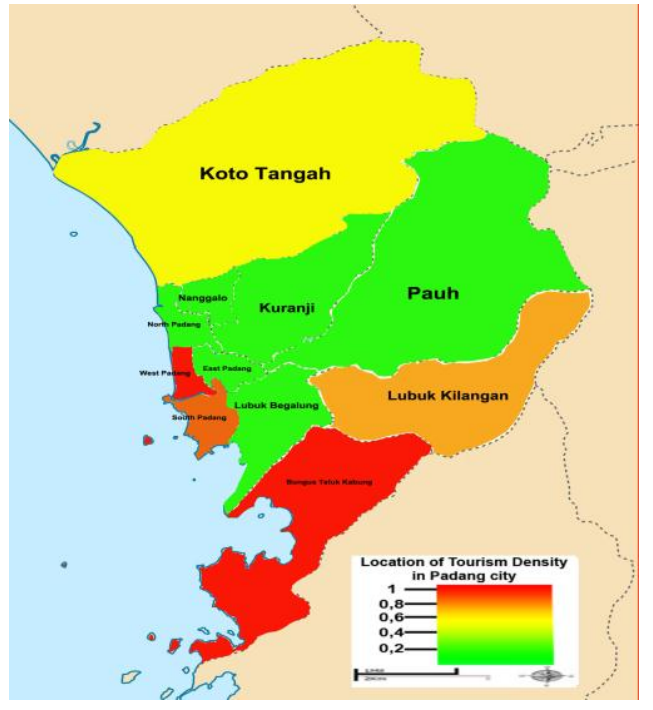

Fig. 2: Distribution of Tourism Locations in Padang

Based on the map above, it is apparent that the area with the most tourism destinations is those in strong red, meanwhile the least destinations in light green.

The classification of level of tourism destinations based on the total score obtained using SAW method in complete is as follows:

1. Minimum distribution, with score weight of $0-0.2$

2. Medium distribution, with score weight of 0.2-0.6

3. Maximum distribution, with score weight of 0.6-1

The result of tourism destinations mostly lies in West Padang and Bungus Teluk Kabung Sub-District with 7 and 8 tourism locations considered having the potential for tourism business by creating new entrepreneurial areas to boost the local people's income.

\section{CONCLUSION}

Based on the results obtained and analysis done in this research, then it could be inferred as follows:

1. The designed SAW method could display the distribution of tourism destinations

2. The display of distribution of tourism destinations such as color change variation where green represents minimum amount of tourism distribution and green the maximum amount of it.

3. Based on the color of distribution of tourism destination in West Padang, and Sub-District Bungus Teluk Kabung has the highest distribution level of the tourism destinations during the period of this research.

4. It is hoped that this research could be a contribution in boosting tourism businesses by creating new tourism areas that could boost the local people's income.

\section{ACKNOWLEDGEMENTS}

We would like to thank STMIK Indonesia for financial support. 


\section{REFERENCES}

[1] Rencana Strategi (Renstra), Dinas Kebudayaan dan Pariwisata Kota Padang , 2014-2019 pp. 79-80.

[2] Guswanto, Dasar dan Aplikasi Sistem Informasi Geografis , Badan Meteorologi Klimatologi dan Geofisika, 2007.

[3] Kusumadewi, Sri and Purnomo, Hari., 2010, Aplikasi Logika Fuzzy untuk Pendukung Keputusan, Yogyakarta : Graha Ilmu.

[4] Michailidis, A. and Chatzitheodoridis, F., "Scenarios Analysis of Tourism Destinations", Journal of Social Sciences, papers 2 (2): 41-47, (2006).

[5] Olabintan D.D and Ajirotutu, J.O, (2012). Application of Geographic Information System (GIS) in Tourism Mapping for Sustainable Tourism Development in Owo Local Government Area (LGA), Ondo State, Nigeria. Paper Presented on 4th International Conference on Educational and New Learning Technologies. Barcelona, Spain. Available on line at www.library.iated.org/view/OLABINTAN2012APP. Retrieved on 20th of May, 2017.

[6] I. O. Bildirici, and N.N. Ulugtekin. (2010), "Web mapping with google maps mashups: overlaying geodata," ASPRS/CaGIS 2010 Fall Specialty Conference November 15-19, 2010 Orlando, Florida Available :

http://www.isprs.org/proceedings/XXXVIII/part4/files/Bildirici.pdf [7] Staab, Steffen, (2006), Semantic Web and Peer to Peer, SpringerVerlag, Berlin.

https://doi.org/10.1007/3-540-28347-1 